\title{
Virtual Reality Media: The Simulation of Relativity Theory on Smartphone
}

\author{
Dadan Sumardani ${ }^{1}$ (*), Agustiani Putri ${ }^{2}$, Rahma Rosaliana Saraswati ${ }^{3}$, Dewi \\ Muliyati $^{4}$, Fauzi Bakri ${ }^{5}$ \\ 1,4,5 Pendidikan Fisika, Universitas Negeri Jakarta, Indonesia \\ ${ }^{2,3}$ Pendidikan Matematika, Universitas Negeri Jakarta, Indonesia
}

\begin{abstract}
Received: October 23, 2019

Revised: February 27, 2020

Accepted: February 28, 2020

Learning physics science is ideally accomplished through the experiments, although the theory of special relativity is challenging to understand. It is difficult because this topic has not occurred in real experience, and no technology has launched at the speed of light. To understand this theory, Virtual Reality (VR) can potentially visualize the actual concept of relativity by presenting an artificial environment to the students. This research aims to develop the virtual reality application as a learning media for special relativity. This Research and Development uses the Lee and Owens Model, which consists of analysis, design, development, implementation, and evaluation. The system development method used is black-box testing. The result of the system development is the creation of a VR application to explain the material of relativity. From the results of black-box testing, the test results show that the percentage of application system success is $83 \%$. It indicates that the application is functioning correctly on smartphone usage so that this application can be used on the theory of relativity simulation users using virtual reality devices.
\end{abstract}

Keywords: Learning Media, Relativity Theory, Virtual Reality.

(*) Corresponding Author: dadansumardani_pfisika15s1@mahasiswa.unj.ac.id

How to Cite: Sumardani, D., Putri, A., Saraswati, R.R., Muliyati, D., \& Bakri, F. (2020). Virtual reality media: The simulation of relativity theory on smartphone. Formatif: Jurnal Ilmiah Pendidikan MIPA, 10 (1): 13-24. http://dx.doi.org/10.30998/formatif.v10i1.5063

\section{INTRODUCTION}

Learning physics is ideal for interacting with nature through experimental activities or practicum (Suparno, 2005). The emergence of the theory of relativity proposed by Einstein formed new concepts about space and time. As a result of the development of Einstein's postulates, time-lapse, length contraction, mass contraction, and twin paradox occur. Things like this are difficult to understand for students who are studying modern physics because it seems as if they are contrary to their daily experiences (Hartono, 2007). Scientists and physics teachers, from time to time, always look for ideas on how to convince people about the theory of relativity logically so that it is easy to understand (Kustanto \& Octova, 2016).

Difficulties experienced by students in learning modern physics are due to the concepts they have obtained through everyday empirical experience. In contrast, the concepts of modern physics appear to conflict with their skills. Another factor that is also the cause is the nature of contemporary physics concepts that are dominated by abstract concepts (Pospiech, 1999). Providing a good understanding of the theory of relativity can use regular accelerated motion events and emphasize the local review of each object regarding the exchange of light signals (Müller et al., 2008). Also, to facilitate the acceptance of the theory, media are needed that can realize the concept of relativity, 
which is considered unreal to be a real reality and felt by the five senses. The abstract concept will be easily understood by using Virtual Reality learning media (Alqahtani, 2017; Sumardani, 2019).

Virtual reality arises from a prototype of a vision built by Morton Heilig in 1962 called Senosorama. Subsequent developments Google finally released the Google Cardboard application as an inexpensive Virtual Reality buffer application and made the Unity plugin. This condition supports the rapid growth of Virtual Reality (Mandal, 2013; Dougherty, 2015; Eadicicco, 2016; Pierce, 2015).

VR is already in providing interactive media that can affect the user's senses so that users dissolve into a simulated environment (Mihelj et al., 2014). VR can present an artificial world and try things that are not accessible in real life and present them in the user's view (Mandal, 2013; Smith, S. \&. Lee, 2004). VR has long been used for education and various simulations. These simulations have been developed, such as aircraft operations, tanks, power generation systems, and human surgery (Jin, 2011; Onyesolu, 2006). Many innovations occur because of the power of Virtual Reality in convincing users and ensuring their presence in an artificial environment (Wittenberg, 1993). This technology was introduced as an innovative device to solve complicated problems, resulting in unique, realistic, and practical solutions for students (Kartiko et al., 2010).

Research on the development of instructional media using virtual technology and augmented reality in the form of simulations has been widely carried out in the world of education. It is for in facilitating students in practising in the way of student worksheets in laboratories (Bakri et al., 2019; Sumardani et al., 2020), augmented textbooks to improve student skills (Bakri et al., 2019), educational posters with augmented reality (Sumardani et al., 2019), and simulation- simulations used to visualize concepts from physics (Muliyati et al., 2019). The educational research is based on the rapid use of technology that cannot be ignored in the 21 st-century intervention.

Research from a science teacher named Winn and Bricken, who uses Virtual Reality to explain abstract mathematical material, concludes that Virtual Reality has the potential to significantly increase student learning (Winn \& Bricken, 1992). Furthermore, research by Moses, which uses Virtual Reality in analyzing vector and descriptive geometry, shows that students assess VR as an excellent place of experimentation and can think more easily to understand the concept of the material (Okechukwu \& Eze, 2011).

Based on the background stated, researchers are interested in developing the Virtual Reality application as a Learning Media for Special Relativity on Google Cardboard Android Smartphones.

\section{METHODS}

The method used in this research is Research and Development using the Lee and Owens Model, which consists of 5 stages, namely analysis, design, development, implementation, and evaluation. In this study, the Lee and Owens Model will be specialized in the component development process, which generally includes three stages, namely pre-production, production, and post-production (Lee \& Owens, 2004). The system development method also used the black-box testing, which ends with support for the complete software produced. 
In the pre-production stage, the activity undertaken is to create a storyboard to provide an overall picture of products. At the production stage, it will be described how to create a virtual reality application to give a detailed description of the application creation process. In the post-production stage, the researchers conducted the necessary reviews and improvements so that the product could run on an Android smartphone.

\section{RESULTS \& DISCUSSION}

\section{Results}

\section{Pre-Production}

At the pre-production stage, equipment used in the research was prepared including a set of computers, physics reference books, smartphones with Android operating system equipped with a gyroscope, internet connection, Unity 5.6.2f1 software, Google Cardboard (online), and Adobe Premiere software (offline). The physics reference book used in this study is the 9th Introduction to Physics by authors John D. Cutnell \& Kenneth W. Johnson, published by Wiley.

\section{Production}

At the production stage, a set of computer equipment, internet connection, Unity 5.6.2f1 software, Google Cardboard (online) and Adobe Premiere software (offline) are used. The computer specifications used, as shown in Figure 1 below.

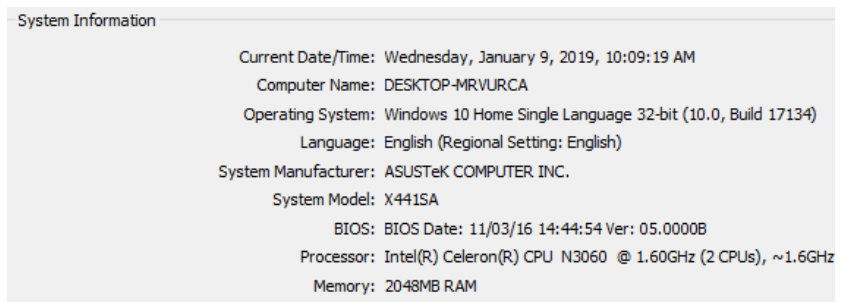

Figure 1. Computer specifications used

Following are the steps in designing learning media in the form of Google Cardboard-based Virtual Reality applications on android devices:

Open the Unity application that has been installed. Select projects $>$ new project $>$ write the name in the project name > select where to save the file in the location > click $3 \mathrm{D}>$ then create project to enter the unity a project.

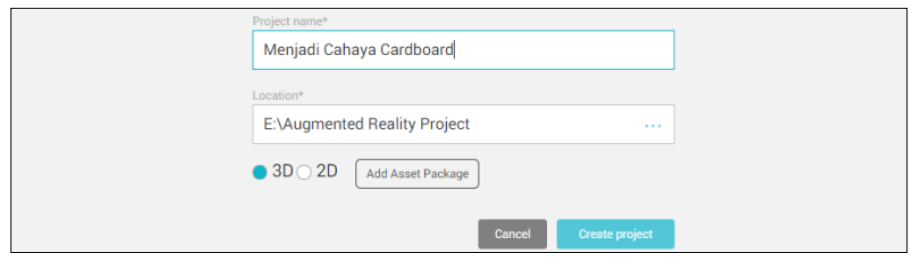

Figure 2. New Project Panel Display

In the Unity 5.6.2 display, set Main Camera and Directional Light to position $(0,0,0)$, then right-click on the active scene $>$ click 3D Object $>$ Click sphere, then set the sphere position to $(0.0,0)$, rotation $(0.0,0)$ and the scale used is changed to $(50.50 .50)$. 
Making a sphere is as a ball-shaped screen and the observer is placed in the center of the ball.

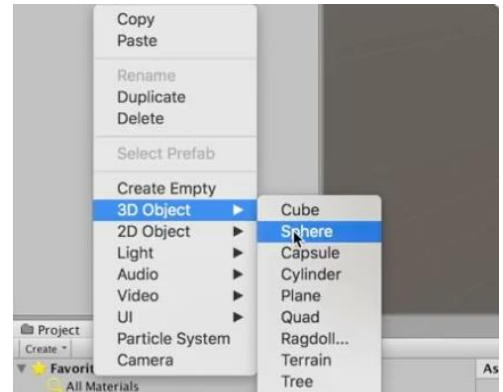

(a)

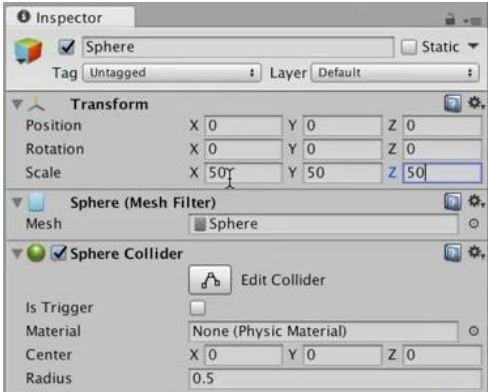

(b)

Figure 3. (a) Adding Ball Objects, (b) Configuring Ball Settings.

In the assets unity folder, right-click on the assets folder> Create> Shader> Standard Surface Shader > left click > rename to FlippingNormal. Then next on the Inspector task pane, left click on the show generated code and program it using $\mathrm{C} \#$ language.

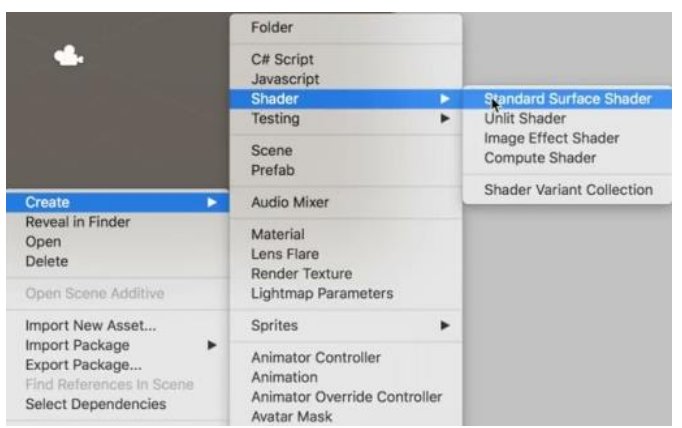

(a)

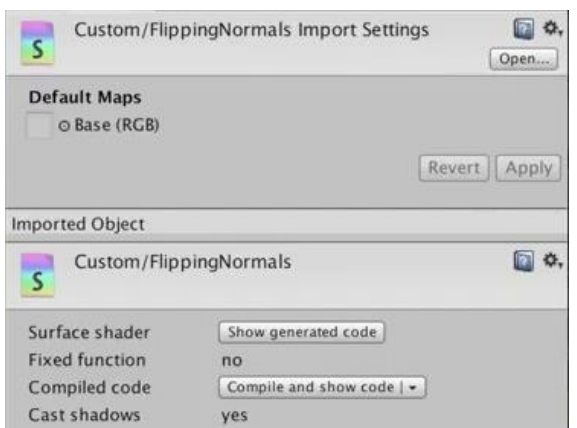

(b)

Figure 4. (a) Adding Shaders to Assets, (b) Inspector Shader Flipping Normal.

Next in the assets unity folder, right-click on the assets folder $>$ Create $>$ Material $>$ Left Click. Then rename the material to SphereMat, and drag SphereMat to the Object Sphere in the Active Scene section.

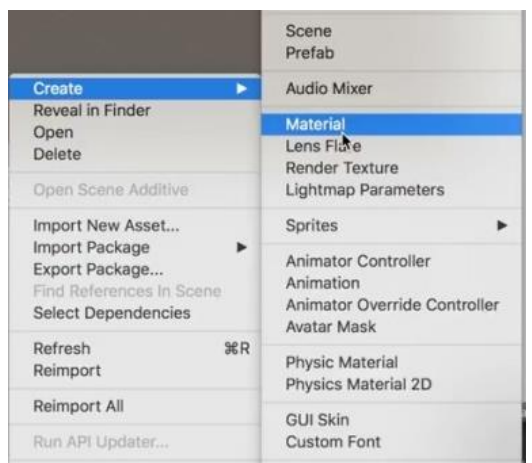

(a)

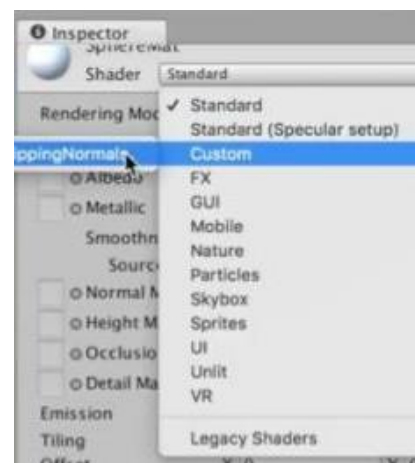

(b)

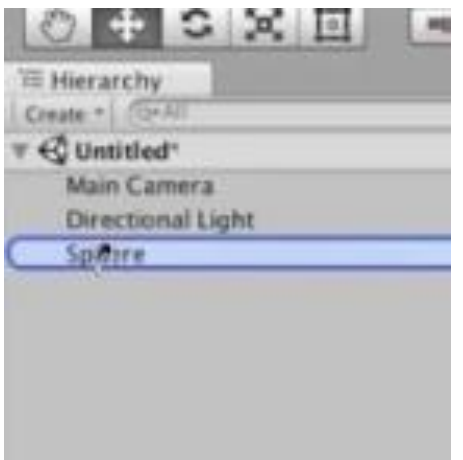

(c)

Figure 5. (a) Add material to Assets, (b) change the format, (c) Drag Material

To create content in Virtual Reality, you need Video 360, which can be downloaded on the website of Video 360 providers or you can make it with the Google 
360 Application. When the video has been downloaded > import into Unity by dragging it from the download folder into the Unity work screen. Furthermore, when it is available in Unity assets > drag the video to the Object Sphere in the active Scene > when the drag process is successful, the video player will look like Figure 6.

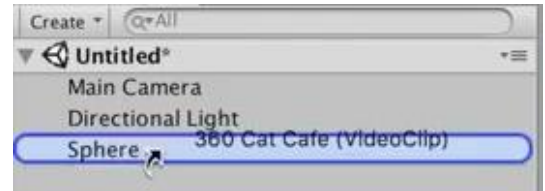

(a)

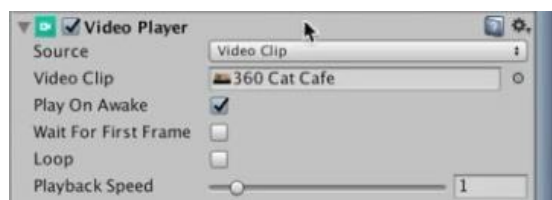

(b)

Figure 6. (a) Drag the Video File to the Ball Object, (b) Video Player Configuration

Download the Google VR Cardboard for the unity platform > then click Get Started to download. Google Cardboard support can be accessed https://developers.google.com/vr/ then download unitypackage to support the Virtual Reality application.

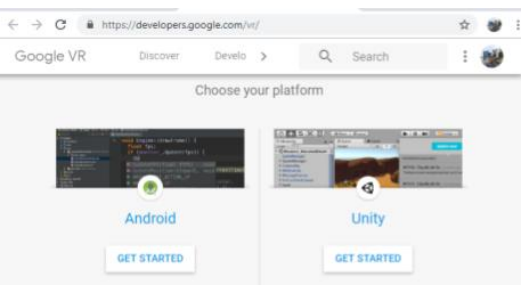

(a)

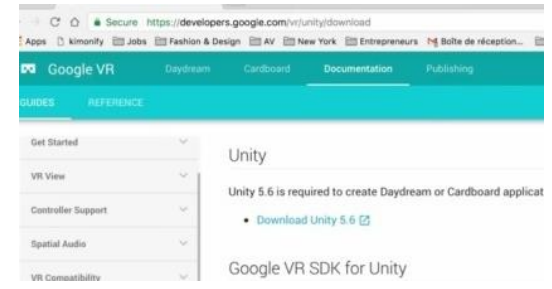

(b)

Figure 7. (a) Selecting an Application Platform, (b) Download the Google VR Unitypackage download link.

Import unitypackages into the Unity work screen by clicking the assets menu > import package > custom package > find a location where you can download google VR Support $>$ Click Open. Then the whole packages will appear that will be imported into Unity > click import.

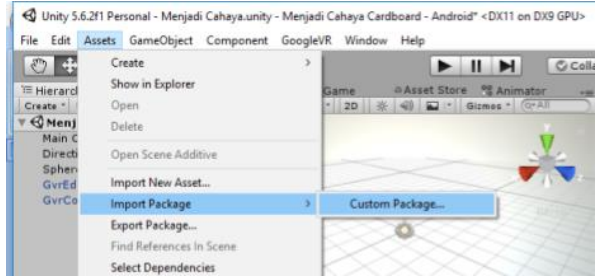

(a)

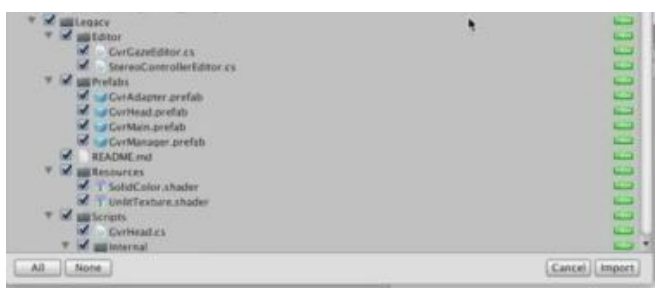

(b)

Figure 81. (a) Import Custom Packages from a Folder, (b) Select Imported Components

After importing Google VR Cardboard to unity, open the Assets / GoogleVR / Prefabs folder > Drag the GvrEditorEmulator.prefab file to the Active Scene > then open the Assets / GoogleVR / Prefabs / Controller folder > Drag the GvrControllerMain.prefab file to the Active Scene. 


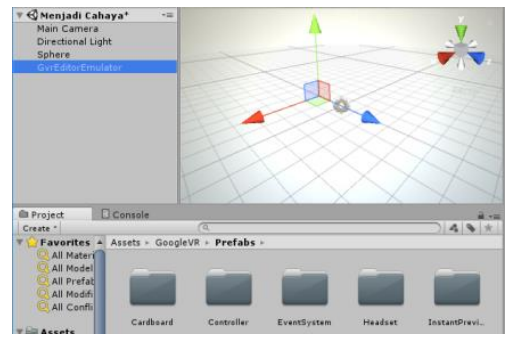

(a)

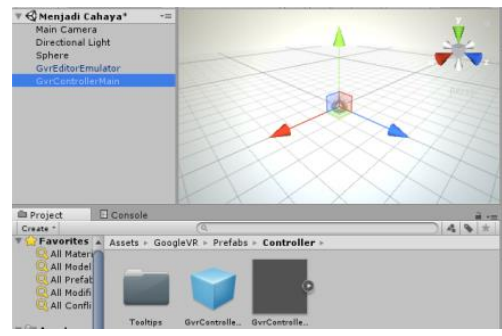

(b)

Figure 92. (a) Adding the Gvr Editor Emulator, (b) Adding the Main Gvr Controller.

Manage external tools by selecting edit > preferences > external tools > click download, and will automatically open the page to download sdk and jdk.

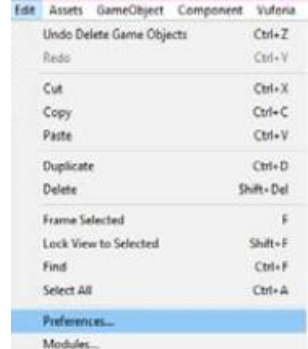

(a)

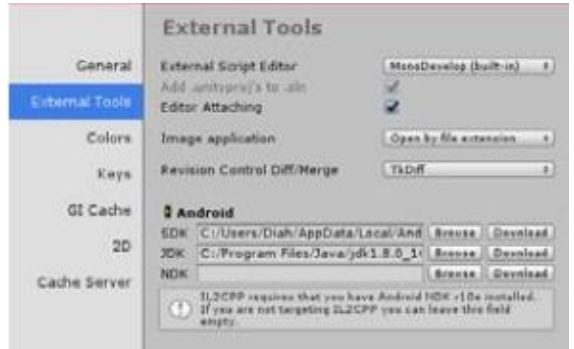

(b)

Figure 103. (a) Setting Application Preferences, (b) Set the external Unity tool

Before building the Application Build process, click File > click Build Settings > Then after the Build Settings Panel appears > Click Add Open Scenes > click on the android platform > then click Switch Platform. Next to set the identity of the application, click player settings and fill in the Company Name and Product Name and the Application Icon, Identify the Minimum Mobile and Application Version. Then to run VR, click Virtual Reality Support in Configuration > Add Cardboard. After the application identification process is complete, then click do build the application by clicking Build > Select Storage directory > Click Save.

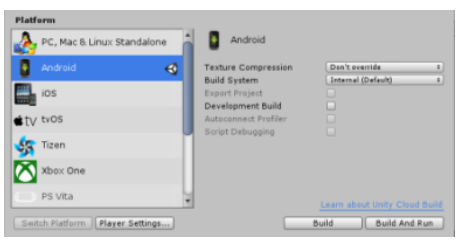

(a)

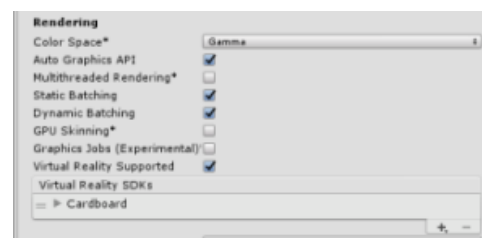

(b)

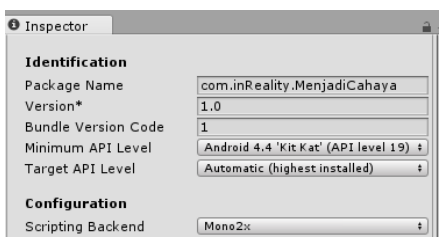

(c)

Figure 11. (a) Build Settings, (b) Identity Configuration, (c) Configuration Specifications.

\section{Post Production}

After the application is made, testing is done by experimenting with the function of the virtual reality application device. The test will be tested by testing the application response, accelerometer sensor and Gyroscope. Tests carried out by rotating the device either with a roll, pitch, or yaw position. Then the suitability of the image shift when the device is moved will be an essential part that will be tested because the relevance is very influential on whether or not the virtual world presented to users. 
Some of the tests performed in the virtual reality application response process are shown in Table 1. The experiments were performed using an android smartphone with an android system 8.1.0 (Android Oreo System) and using Virtual Reality Gear glasses. Testing on applications that have been developed is then carried out using black-box testing. The results are displayed, and the expected results are shown in Table 1 below.

Table 1. Results of Black-box Assessment Test

\begin{tabular}{|c|c|c|c|}
\hline No & Testing & Information & Results \\
\hline 1 & $\begin{array}{l}\text { Download the application from } \\
\text { the web }\end{array}$ & Downloaded on smartphone & Success \\
\hline 2 & $\begin{array}{l}\text { Install the application on a } \\
\text { smartphone }\end{array}$ & $\begin{array}{l}\text { Application installed on the } \\
\text { smartphone }\end{array}$ & Success \\
\hline 3 & Open the application list & $\begin{array}{l}\text { The application icon appears on } \\
\text { the menu }\end{array}$ & Success \\
\hline 4 & Open the application & Open applications smoothly & Success \\
\hline 5 & $\begin{array}{l}\text { Click the open application } \\
\text { menu }\end{array}$ & $\begin{array}{l}\text { The unity opening menu } \\
\text { appears }\end{array}$ & Success \\
\hline 6 & Directing the VR pointer & The main VR menu appears & Success \\
\hline 7 & $\begin{array}{l}\text { Click the menu through the } \\
\text { head movement }\end{array}$ & The pointer moves & Success \\
\hline 8 & Click the next menu & $\begin{array}{l}\text { The application displays next } \\
\text { scenes }\end{array}$ & Failed \\
\hline 9 & Click the pause menu to stop & $\begin{array}{l}\text { The application has stopped } \\
\text { running }\end{array}$ & Success \\
\hline 10 & Click the back menu & $\begin{array}{l}\text { The application opens the } \\
\text { previous scene }\end{array}$ & Failed \\
\hline 11 & Click the hint menu & $\begin{array}{l}\text { The application displays the } \\
\text { help text }\end{array}$ & Success \\
\hline 12 & Move the head $360^{\circ}$ degrees & $\begin{array}{l}\text { The VR world rotates in the } \\
\text { direction of the head }\end{array}$ & Success \\
\hline
\end{tabular}

The test results show that of several test items. The following results are shown in Table 2 below.

Table 2. Description of Testing Application

\begin{tabular}{cccc}
\hline Results Test & Ordinal & Total & Persentase \\
\hline Success & 1 & 10 & $83,33 \%$ \\
Failed & 0 & 2 & $16,67 \%$ \\
\hline
\end{tabular}

From the test results obtained that the percentage of the success of the function in the developed application system is $83.33 \%$ already functioning correctly. The progress of the order was reviewed from 10 items that successfully passed the test, including the installation process that went smoothly and the VR world viewer that went in the direction of the user's head. At the same time, there is a system failure of $16.67 \%$ in the application of some of the items tested, namely the next and back buttons on the virtual reality application menu. 


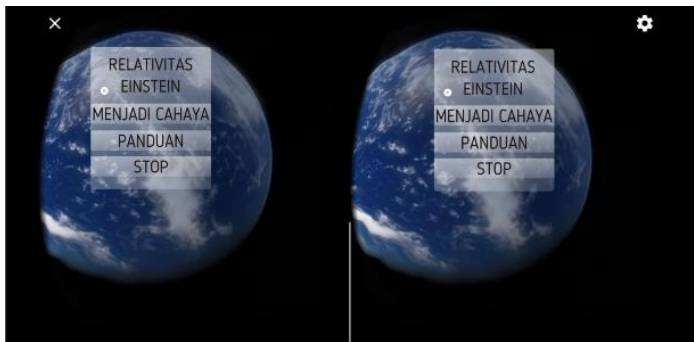

(a)

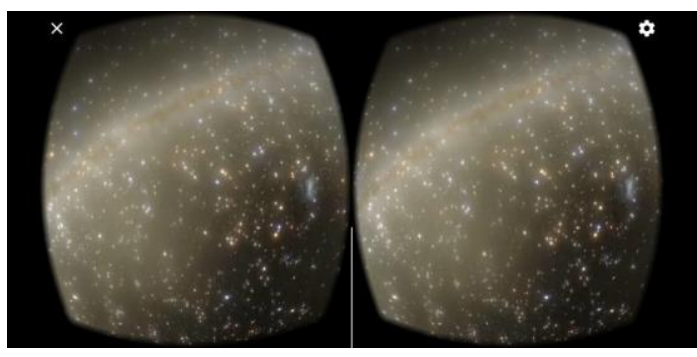

(c)

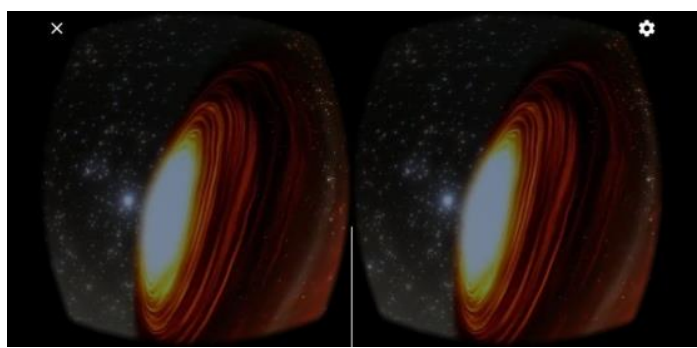

(e)

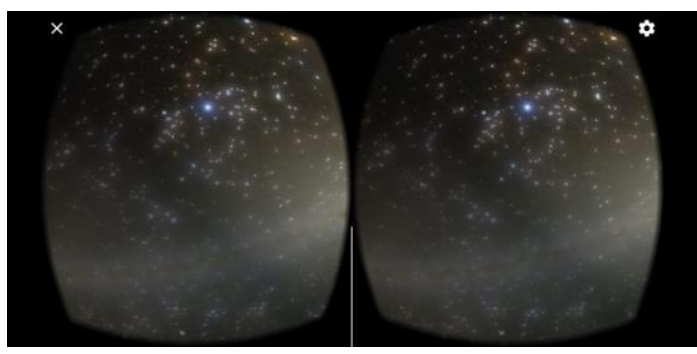

(g)

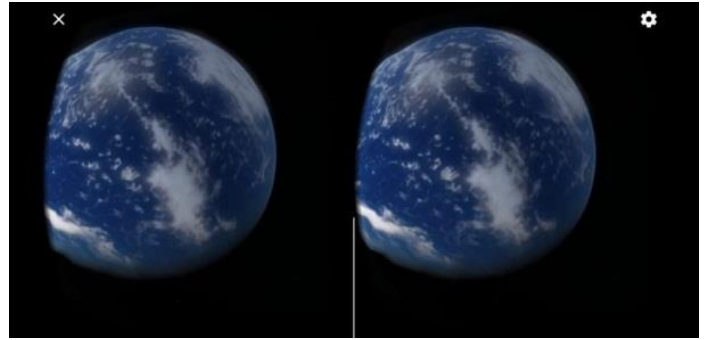

(b)

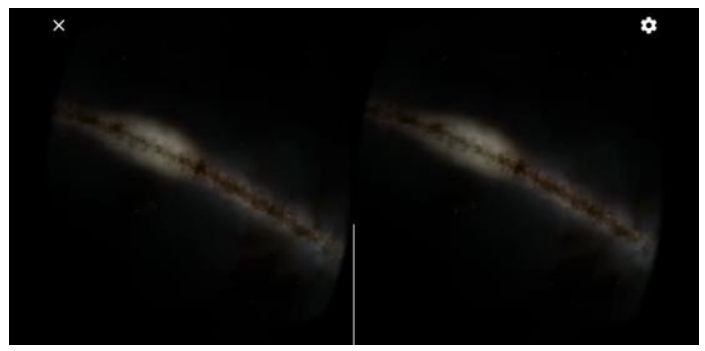

(d)

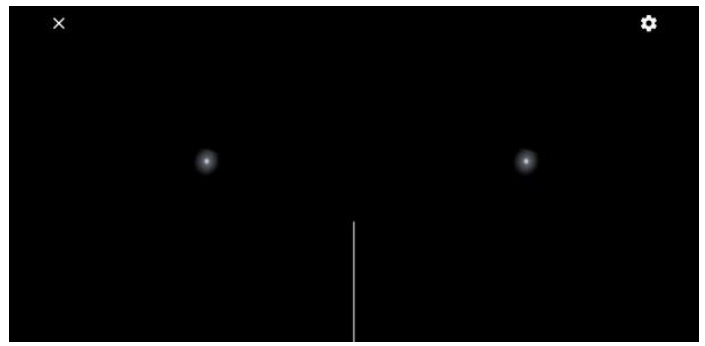

(f)

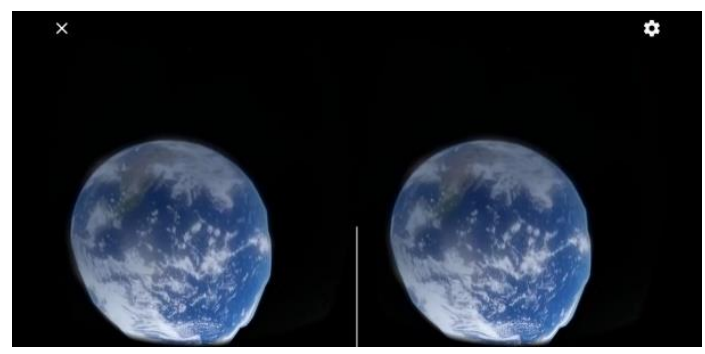

(h)

Figure 4. VR sky perspective with gyroscope sensor on smartphone,

(a) command menu in the application, (b) scene out of the earth, (c) scene away from the center of the solar system, (d) scene away from the center of the galaxy Milky way, (e) scene enter a black hole, (f) the scene inside the black hole, (g) the scene after exiting the black hole, (h) the scene returns to earth.

The picture shows some test results on the virtual reality application and some scenes on the application. Based on testing, the application looks smooth and has no problems. 


\section{Discussion}

This research aims to develop the virtual reality application as a learning media for special relativity. The method used in this research is Research and Development using the Lee and Owens Model. This research also uses black-box testing to evaluate the development system.

In the pre-production stage, an application storyboard is created. The information to be conveyed through this virtual reality application is a human journey when travelling at the speed of light. Moving at the speed of light will cause several events to occur. These events are long contractions, shortening of time, mass melting into energy, and twin paradoxes. This event had never happened in reality, but it was confirmed in theory. By using Virtual Reality technology and the virtual world, this concept can be witnessed by the senses of the user as if the real event happened. This application is displayed with a blend of real and virtual world concepts that are visualized by virtual reality applications.

At the production stage, this application was developed using open-source software, Unity 5.6.2f1. This application has advantages in using it offline and easy in making content, so researchers are interested in using this application. Other equipment is a set of computers with Intel (R) Celeron (R) CPU N3060 @ $1.60 \mathrm{GHz}$ CPU specifications and RAM $2048 \mathrm{Mb}$. The physics reference book used is the 9th Introduction to Physics by authors John D. Cutnell \& Kenneth W. Johnson, published by Wiley. This application will be saved in .apk format and can be downloaded via the android play store. Content on the application will be created using Adobe Premier and saved in .mp4 format. This application also requires an internet connection to access the Google VR Cardboard for the unity platform. Google VR Cardboard can be downloaded open source at https://developers.google.com/vr/ access.

In the Post-Production stage, testing is done by testing the application response, accelerometer sensor, and Gyroscope. The test is done by rotating the device either with a roll, pitch, or yaw position adjusting to the direction of rotation of the user's head using Virtual Reality Gear glasses. From the results of black-box testing, the test results obtained that the percentage of the success of the function in the developed application system is $83.33 \%$ already functioning properly. The success of the system was reviewed from 10 items that successfully passed the test, including the installation process that went smoothly and the VR world viewer that went in the direction of the user's head. While there is a system failure of $16.67 \%$ in the application of some of the items tested, namely the next and back buttons on the virtual reality application menu. The rightness of the application transformation, when moved, will be an important part that will be tested because the relevance is very influential on whether or not the virtual world presented to users. The test was performed using an android smartphone with the android system 8.1.0 (Android Oreo System) with the trademark Samsung A7 and Virtual Reality Gear branded with VR BOX. Testing of virtual reality devices results in the conclusion that the application runs very smoothly on the smartphone, and the content is clearly visible.

The advantages of this application include being able to help users understand the way light moves and take advantage of the latest technology in the world of education, namely virtual reality. The development of virtual reality must be developed more massively in learning media in schools so that the availability of learning media in Indonesia can be more diverse. 


\section{CONCLUSION}

This research has been carried out with the initial aim of giving a presentation on how to develop virtual reality technology quickly, cheaply, and effectively using the Unity 5.6.2f1 software. The result of this research is the creation of a Virtual Reality application to help understand the concept of the theory of relativity. After testing with the black-box testing method, the test results obtained that the percentage of success in this application system is $83.33 \%$ already functioning properly on smartphone usage so that this application can already be used by users in the learning process.

\section{REFERENCES}

Alqahtani, A. S. (2017). Environments and System Types of Virtual Reality Technology in STEM : A Survey. International Journal of Advanced Computer Science and Applications, 8(6), 77-89.

Bakri, F., Marsal, O., \& Muliyati, D. (2019). Textbooks Equipped with Augmented Reality Technology for Physics Topic in High-School. Jurnal Penelitian \& Pengembangan Pendidikan Fisika, 5(2), 113-122.

Bakri, F., Sumardani, D., \& Muliyati, D. (2019). Integrating augmented reality into worksheets: Unveil learning to support higher-order thinking skills. AIP Conference Proceedings 216920012.

Dougherty, C. (2015). Google Intensifies Focus on its Cardboard Virtual Reality Device. Retrieved January 5, 2019, from www.nytimes.com/2015/05/29/technology/googleintensifies-focus-on-its-cardboardvirtual-reality-device.html.

Eadicicco, L. (2016). Google's Cheap Virtual Reality Headset Is About to Get Better. Retrieved January 8, 2019, from http://time.com/4180621/googlecardboard-headset.

Hartono. (2007). Melatih Kemampuan Berpikir Alternatif Melalui Pembelajaran Fisika Modern. In SEMINAR NASIONAL MIPA 2007. Yogyakarta: Fakultas Matematika dan Ilmu Pengetahuan Alam UNY.

Jin, W. (2011). Virtual reality technology in the design of the space environment research. 2011 International Conference on Control, Automation and Systems Engineering.

Kartiko, I., Kavakli, M., \& Cheng, K. (2010). Learning science in a VR application: The impacts of animated-virtual actors' visual complexity. Computers \& Education, 55(2), 881-891.

Kustanto, H., \& Oktova, R. (2016). the Twin Paradox in the Theory on Special Relativity As an Enrichment Topic for High School Physics. Berkala Fisika Indonesia, 8(1), $10-16$.

Lee, W., \& Owens, D. . (2004). Multimedia Based Instructional Design, Second Edition. San Fransisco: Pfeiffer.

Mandal, S. (2013). Brief Introduction of Virtual Reality \& its Challenges. International Journal of Scientific \& Engineering Research, 4(4), 304-309.

Mihelj, M., Novak, D., \& Beguš, S. (2014). Virtual Reality Technology and Applications (Vol. 68). (S. G. Tzafestas, Ed.) New York, London: Springer.

Muliyati, D., Sumardani, D., Ambarwulan, D., Siswoyo, S., Handoko, E., Fitriani, E., \& Viridi, S. (2019). The 3-D visualization of the granular particle on various diameter porous surfaces. Journal of Physics: Conference Series 140277026.

Müller, T., King, A., dan Adis, D. (2008). A trip to the end of the universe and the twin "paradox." Am. J. Phys., 76(4), 360-373.

Nugroho, R. A. (2018). HOTS (Higher Order Thinking Skill). Jakarta: Grasindo. 
Okechukwu, M., \& Eze, F. (2011). Understanding Virtual Reality Technology: Advances and Applications. Advances in Computer Science and Engineering, Matthias Schmidt, IntechOpen.

Onyesolu, M. O. (2006). Virtual reality: An emerging computer technology of the 21st century. International Journal of Electrical and Telecommunication Systems Research, 1(1), 36-40.

Pierce, D. (2015). Google Cardboard is VR's Gateway Drug. Retrieved January 8, 2019, from http://www.wired.com/2015/05/try-googlecardboard/

Pospiech, G. (1999). Teaching the EPR paradox at high school?. Physics Education, 34(5).

Smith, S. \&. Lee, S. (2004). A pilot study for integrating virtual reality into an introductory design and graphics course. Journal of Industrial Technology, 20(4), $2-7$.

Sumardani, D., Midaraeni, I., Sumardani, N. I. (2019). Virtual Reality Sebagai Media Pembelajaran Relativitas Khusus Berbasis Google Cardboard pada Smartphone Android. Prosiding. Seminar Nasional Pendidikan KALUNI, 2, 309-321.

Sumardani, D., Saraswati, R. R., Putri, A., Bakri, F., \& Muliyati, D. (2020). System Implementation of Augmented Reality Application in Student Worksheet. Jurnal Informatika, 8(1), 10-18.

Sumardani, D., Wulandari, A., \& Doriza, S. (2019). Penerapan Teknologi Augmented Reality Pada Media Pembelajaran Poster Tatasurya. Prosiding Seminar Nasional Fisika (E-Journal), 8, 451-456.

Suparno, P. (2005). Miskonsepsi \& perubahan konsep dalam pendidikan fisika. Jakarta: PT. Grasindo.

Winn, W., \& Bricken, W. (1992). Designing virtual worlds for use in mathematics education: The example of experiential algebra. Educational Technology, 32(12), $12-19$.

Wittenberg, G. (1993). Virtual reality in engineering. The Industrial Robot, 20, 21-22. 
Sumardani et al. / Formatif: Jurnal Ilmiah Pendidikan MIPA 10(1), 13-24

This page intentionally left blank. 